\title{
Occurrence of tin in disposable baby diapers
}

\author{
Q1 Danijela Šmajgl and Jasmina Obhođaš*
}

\begin{abstract}
Concentrations of tin were measured in six different brands of disposable baby diapers by using radioisotope (americium) excited energy dispersive $X$-ray fluorescence. Top sheet and adhesive tape system were measured separately. The concentrations found in top sheet and tape system were $<1.5$ to $23.1 \mathrm{mg} / \mathrm{kg}$ and $<1.5$ to $22.4 \mathrm{mg} / \mathrm{kg}$, respectively. Almost all diapers contained tin in the adhesive tape system (four of five), and two of six samples contained tin in top sheet. Tin found in diapers may be an organotin substance: tributyltin (TBT), dibutyltin (DBT), monobutyltin (MBT) and/or dioctyltin (DOT), which are widely used in industrial processes as catalysts or as PVC heat stabilizers. Organotin substances have toxic effects which include neurotoxicity, reproductive and developmental toxicity, immunotoxicity and endocrine disruption. The measured concentrations were less than EU regulatory levels of $0.1 \%$ by weight of tin prescribed by REACH Annex XVII No 20 . However, the same regulation completely bans the use of organotin substances as biocides in antifouling paints. While effects of TBT on marine organisms from antifouling paints are well known, the effects of organotin compounds in childcare products and other commercial articles receive much less attention. Children who use disposable diapers every day are particularly sensitive. Copyright @ 2015 John Wiley \& Sons, Ltd.
\end{abstract}

\section{Introduction}

Inorganic tin is used in production of various organotin compounds which are commonly present in our households manly because of the fact that organotins are widely used as PVC stabilizers, as catalysts for various products, in certain esterification and transesterification reactions and as biocides and pesticides. The organotin compounds used as biocides in antifouling paints are listed as restricted substances in theAnnex XVII to REACH Regulation. However, the same regulation allows usage of organotins in some products in the use by general public including baby diapers, in concentrations equal to or greater than $0.1 \%$ of tin weight in the article, or part thereof. In view of organotin harmfulness, protection measures of marine environment are generally very strict compared to direct measures undertaken for human health protection. For example, limits between 0.1 and $0.5 \mathrm{mg} \mathrm{Sn} / \mathrm{kg} \mathrm{dw}$ in sediments are set as contamination upper limits for sea disposal of dragged sediment material in different countries around the world. ${ }^{[1,2]}$

The tin in baby diapers occurs in the form of organotin compounds. The most common is dibutyltin (DBT) followed by monobutyltin (MBT) and tributyltin (TBT). Dioctyltin (DOT) is mostly present in the adhesive tape system. These organic derivates of tin are toxic and may accumulate in living organisms. The 'Risk assessment studies on targeted consumer applications of certain organotin compounds' notes that the organotins in diapers could be present as a result of the top sheet being made of siliconegrafted polypropylene or because of its use as a catalyst in the production of an antioxidant in polyolefin films. ${ }^{[3]}$

In this study we analyzed the whole content of tin by using the energy dispersive X-ray fluorescence (EDXRF) with ${ }^{241} \mathrm{Am}$ radioactive source. The content of tin was measured in the top sheet and adhesive tape system used for fastening the disposable baby diaper. Six different brands were collected from stores in Croatia from 2012 to 2014. Diapers top sheet and adhesive tape system are produced by distinguished processes, and differences in tin concentrations are expected. Tin is usually determined as the total metal, but may also be analyzed as specific organotin compound.
The classical speciation analysis of organotin compounds by using gas chromatography (GC) or liquid chromatography (LC) as separation techniques includes extraction, derivatization (for GC), extract purification, enrichment and finally determination and quantification by using different methods such are atomic absorption analysis, inductively coupled plasma atomic emission spectrometry or inductively coupled plasma mass spectrometry. These methods have very low detection limits ( $\mu \mathrm{g} / \mathrm{g}$ to $\mathrm{ng} / \mathrm{g}$ and lower if working with liquid samples). The disadvantage of such multistep analysis is the problem of analyte loss, sample contamination and time consuming procedure. The advantage of the EDXRF over classical analytical techniques is that it requires less sample preparation which helps to prevent contamination, it is non-destructive and whole content of tin can be analyzed in a larger sample volume, which is desirable for analysis of nonhomogenic products such are baby diapers. Therefore, the EDXRF analysis is faster and provides much better reproducibility enabling lower operating cost. The drawback of applied EDXRF setup is in relatively high detection limit of $1.5 \mathrm{mg} / \mathrm{kg}$.

\section{Materials and methods}

Concentrations of tin were measured by using EDXRF in six different brands of disposable baby diapers. Top sheet and adhesive tape system of diapers were separated, cut into very small pieces, homogenized and pressed into thin pellets of $2.5 \mathrm{~cm}$ in diameter weighting about $0.2 \mathrm{~g}$. In addition, a blank sample was made from white cotton by using same procedure. Excitation source was radioactive ring-shaped ${ }^{241} \mathrm{Am}$. Samples were placed in $99.9 \%$ grade aluminum holder $12 \mathrm{~mm}$ distant from the source. The irradiation time * Correspondence to: Jasmina Obhođaš, Ruđer Bošković Institute, Bijenička c. 54,
10000 Zagreb, Croatia. E-mail: jobhodas@irb.hr

Ruđer Bošković Institute, Bijenička c. 54, 10000, Zagreb, Croatia 
was 2000 s. X-ray spectra were collected with a Canberra Ge(Li) detector (GL0055P, FWHM $155 \mathrm{eV}$ at $5.9 \mathrm{keV}$ ). Tin $\mathrm{K} \alpha$ lines were fitted by using IAEA AXIL program, QXAS software package. ${ }^{[4]}$ Standard addition method was used to obtain calibration line for quantitative

F1 analysis of tin concentrations (Fig. 1). After adding the known amount of $\mathrm{Sn}$ certified solution $(1 \mathrm{~g} / \mathrm{l}$ TraceCERT, Fluka, Switzerland) calibrating sample was cut and mixed for $15 \mathrm{~min}$ in agate mortar prior to each analysis and then pressed into a pellet. For each aliquot of $\mathrm{Sn}$ the sample was cut, mixed and analyzed three times. Minimum detection limit (MDL) and error found experimentally were $1.5 \mathrm{mg} / \mathrm{kg}$ and $15.6 \%$, respectively.

\section{Results and discussion}

T1 Table 1 shows results of tin content in top sheet and adhesive tape system of baby diapers obtained by EDXRF with ${ }^{241} \mathrm{Am}$ radioactive source. The results of other studies of organotin compounds in di-

T2 apers are shown in Table 2 . The studies analyzing total tin in diapers have not been found although REACH Regulation requires analysis

F2 of total tin. Figure 2 shows spectra obtained for blank sample made of white cotton and for top sheet of diaper No.2. Because very strong scattering from light organic material additionally excite elements in the radioisotope source and detector collimators, the better results in terms of sensitivity and minimum detection limits are achieved by using thin targets when measuring low tin concentrations.

Organotin toxicity in marine organisms is well studied. It is found that toxic effects increase with an increasing length of alkyl chain and number of alkyl groups per molecule. TBT doses smaller than $2 \mathrm{ng} / \mathrm{l}$ cause imposex for molluscs and chronic and acute toxicity effects in algae, zooplacton and larval fish. Doses higher than $2 \mathrm{ng} / \mathrm{l}$

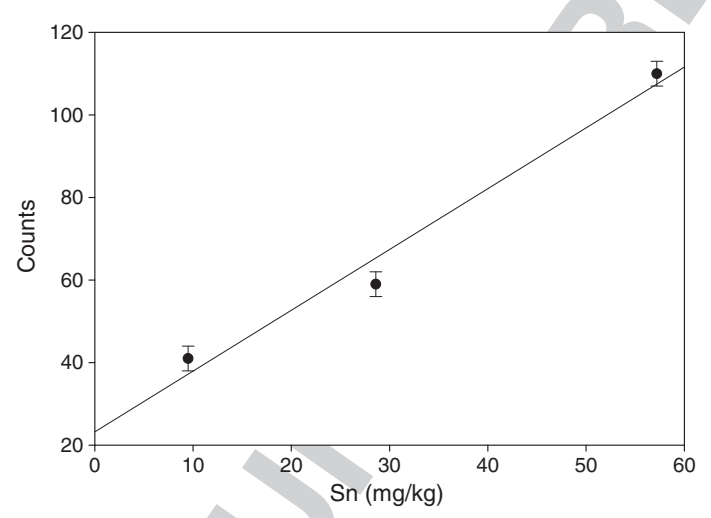

Figure 1. Calibration line obtained by linear regression analysis.

Table 1. Results of tin analysis in top sheet and adhesive tape system of six different types of baby diapers analyzed by the energy dispersive $\mathrm{X}$-ray fluorescence with radioactive ${ }^{241} \mathrm{Am}$ source. Concentrations are in $\mathrm{mg} / \mathrm{kg}$. MDL = minimum detection limit; n.a. = not applicable

\begin{tabular}{|lrc|} 
Analyzed diapers No. & Top sheet & Adhesive tape system \\
\hline 1 & $<\mathrm{MDL}$ & 9.5 \\
2 & 23.1 & 22.4 \\
3 & $<\mathrm{MDL}$ & $<\mathrm{MDL}$ \\
4 & $<\mathrm{MDL}$ & 12.2 \\
5 & $<\mathrm{MDL}$ & n.a. \\
6 & 2.0 & 22.4 \\
\hline
\end{tabular}

Table 2. Organotin compounds in baby diapers reported in other studies

\begin{tabular}{|c|c|}
\hline Product & Organotin cations $(\mathrm{mg} / \mathrm{kg})$ \\
\hline Nappies/diapers ${ }^{[5,6]}$ & 0.023 \\
\hline Nappies/diapers ${ }^{[5,7]}$ & 0.049 \\
\hline Nappies/diapers ${ }^{[5,8]}$ & 0.019 \\
\hline Nappies/diapers ${ }^{[5,9]}$ & 0.024 \\
\hline Nappies/diapers' tape system ${ }^{[5,10]}$ & 47 \\
\hline Nappies/diapers' polyester covers ${ }^{[11,12]}$ & 33.7 \\
\hline Nappies/diapers' nylon covers ${ }^{[10,11]}$ & 5.5 \\
\hline
\end{tabular}

cause intersex for molluscs. ${ }^{[1]}$ Humans are mostly exposed to tin and its compounds by ingestion (mostly by consuming seafood exposed to organotin compounds or by eating food or drinking liquids from tin-lined cans), inhalation (by breathing air or touching dust containing organotin) and through the skin (in contacts with products containing organotin). Although exposure ways of humans are not well studied, laboratory tests on mammals show neurological interferences as most common effects, followed by reproductive and developmental disruptions, immunological effects and endocrine disruptions. There is no evidence of carcinogenic effect of tin and its compounds; however, it is found that they cause adverse effects on NK lymphocytes which are an initial immune defense against the development of tumors or viral infections. ${ }^{[13]}$

The 2012 study of Swedish chemical agency KEMI found no prohibited organotin compounds in 11 different types of baby diapers. ${ }^{[14]}$ However, the restrictions inAnnex XVII of REACH No 20 set the prohibited concentrations of tin in baby diapers rather high, up to $0.1 \%$. According to RPA 2005 report, $^{[3]}$ a significant level of risk which requires risk reduction measures has been identified for children who are exposed to organotins from a range of consumer products. The exposure risk to a child of $8 \mathrm{~kg}$ weight (6- to 8 -month-old baby), based on usage of five diapers daily and
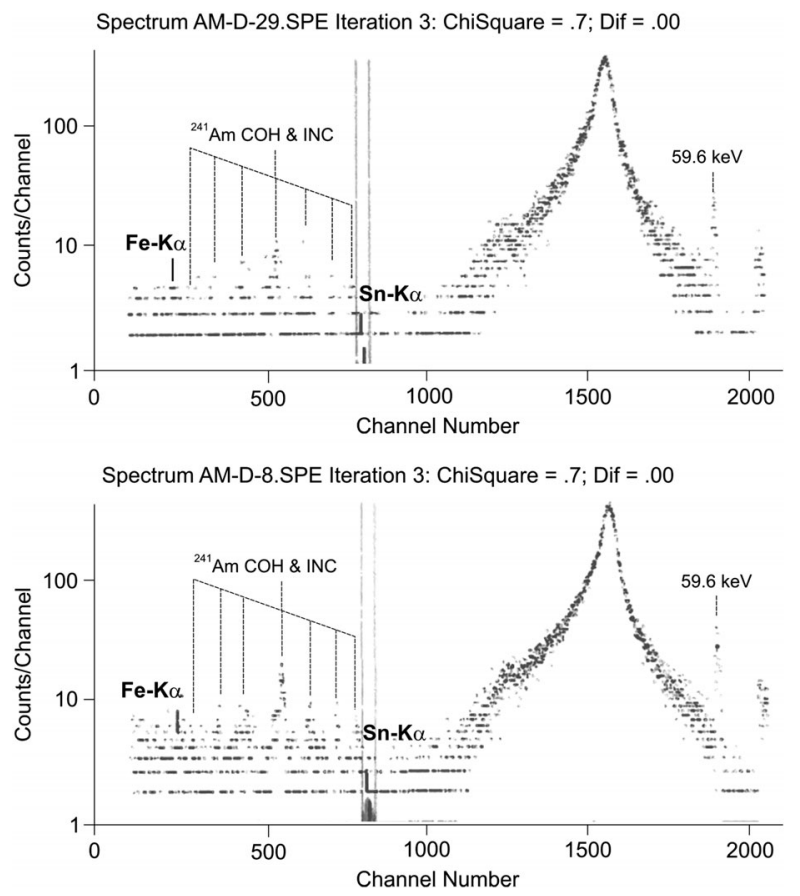

Figure 2. Spectrum obtained for the i) blank target made of white cotton (top) and ii) top sheet of the diaper No2 (bottom). 
worst-case exposure of $0.021 \mu \mathrm{g} \mathrm{Sn} / \mathrm{kg}$ bodyweight/day, was estimated in the range of 20 to $100 \%$ of the tolerable daily intake (TDI). The higher risk can be expected because of environmental exposure and use of other common children products. ${ }^{[3]}$

In EU there are efforts to reduce the content of the organotin compounds in diapers. One of such efforts is undertaken from suppliers of non-woven polypropylene top sheets of babies' diapers who voluntary agreed to set a limit for row material contamination of $<2 \mathrm{mg} / \mathrm{kg}$ for TBT and a limit of $<10 \mathrm{mg} / \mathrm{kg}$ for each species of organotins individually. ${ }^{[15]}$ These values have been indicated as the detection limits for the conventional organotin analytical methods such is gas chromatography. Our results indicate that in spite of the efforts undertaken voluntary by some suppliers to reduce the organotin content in diapers, the risk of exposure of children to tin in diapers is still present.

\section{Conclusion}

In this study we found that tin was present in four of the six analyzed diapers. The highest concentration found in top sheet and adhesive tape system was $23.1 \mathrm{mg} / \mathrm{kg}$ and $22.4 \mathrm{mg} / \mathrm{kg}$, respectively. The prohibited limit of $0.1 \%$ of tin in diapers set by EU Annex XVII of REACH, No 20 is too high and potentially present child exposure risk of concern. The same method may be used for analysis of tin in any organic matrix with a minimum detection limit of $1.5 \mathrm{mg} / \mathrm{kg}$.

\section{References}

[1] M. Staniszewska, B. Radke, J. Namiesnik, J. Bolalek. Intern J Environ Anal Chem. 2008, 88, 747.
[2] W. Manz, F. Krebs, C.A. Schipper, P.J. den Besten, Dutch-German Exchange (DGE) of Dredged Material, Part 5, Status of ecotoxicological assessment of sediment and dragged material in Germany and the Netherlands with the short description of the situation in Belgium, France, and Great Britain, 2007.

[3] RPA, Risk assessment studies on targeted consumer applications of certain organotin compounds. Final Report prepared for the European Commission. Risk \& Policy Analysts Limited (RPA), 2005.

[4] QXAS-Quantitative X-ray Analysis System, version 1.2, open domain software, IAEA, 1995.

[5] WHO, Mono- and disubstituted methyltin, butyltin, and octyltin compounds. United Nations Environment Programme, the International Labour Organization, and the World Health Organization, 2006.

[6] DEPA, Organic tin compounds in consumer products, personal communication received 14 February 2002 from Danish Environmental Protection Agency.

[7] FRG, Notification of a draft Order amending Chemicals Orders (organotin compounds) pursuant to Article 95(5) of the EC Treaty, 2001.

[8] PG, Letter to Danish Environmental Protection Agency from Procter \& Gamble, 10 July, 2000

[9] WEN, Speciated organotin analysis for the Women's Environmental Network. Prepared by Scientific Analysis Laboratories Ltd for the Women's Environmental Network, 24 July (Report No. 18987E/Tin), 2000

[10] RIVM, Health risk assessment for organotins in textiles. Bilthoven, Dutch National

[11] Institute for Public Health and the Environment, January (RIVM Report No. 613350 002), 2000.

[12] K. Kannan, S. Kurunthachalam, J. Giesy. Environ. Sci. Tech. 1999, 33, 1776.

[13] S. Yamada, Y. Fuji, E. Mikami, N. Kawamura, J. Hayakawa. J. AOAC Int. $1993,76,436$.

[14] J. J. Powell, M. L. V. Davis, M. M. Whalen. Drug Chem. Toxicol. 2009, 32, 9.

[15] KEMl, http://www.kemi.se/en/Content/News/No-organotin-compoundsfound-in-diapers, 2012.

[16] RPA, Impact assessment of potential restrictions on the marketing and Q3 use of certain organotin compounds. Final Report prepared for the European Commission, Directorate-General Enterprise and Industry. Risk \& Policy Analysts Limited (RPA), 2007. 


\section{Author Query Form}

\section{Journal: X-Ray Spectrometry}

\section{Article: xrs_2609}

Dear Author,

During the copyediting of your paper, the following queries arose. Please respond to these by annotating your proofs with the necessary changes/additions.

- If you intend to annotate your proof electronically, please refer to the E-annotation guidelines.

- If you intend to annotate your proof by means of hard-copy mark-up, please use the standard proofing marks. If manually writing corrections on your proof and returning it by fax, do not write too close to the edge of the paper. Please remember that illegible mark-ups may delay publication.

Whether you opt for hard-copy or electronic annotation of your proofs, we recommend that you provide additional clarification of answers to queries by entering your answers on the query sheet, in addition to the text mark-up.

\begin{tabular}{|c|l|c|}
\hline Query No. & \multicolumn{1}{|c|}{ Query } & Remark \\
\hline Q1 & $\begin{array}{l}\text { AUTHOR: Please confirm that given names (red) and surnames/family names (green) } \\
\text { have been identified correctly. }\end{array}$ & \\
\hline Q2 & AUTHOR: Please provide the year of publication for Reference 10. & \\
\hline Q3 & $\begin{array}{l}\text { AUTHOR: Reference "16" is not cited in the text. Please indicate where it should be cited; } \\
\text { or delete from the reference list and renumber the references in the text and reference list. }\end{array}$ & \\
\hline
\end{tabular}

